\title{
Evaluation of Procurement Process on Ethanol Factory Construction - Lampung
}

\author{
Roi Milyardi ${ }^{*}$ \\ ${ }^{1}$ Department of Civil Engineering, Faculty of Engineering \\ Universitas Kristen Maranatha, Bandung, Indonesia \\ roi.milyardi@maranatha.edu \\ Indra Koheru ${ }^{2}$, Cindrawaty Lesmana ${ }^{3}$ \\ ${ }^{2} \mathrm{PT}$ Indonesia Ethanol Industry, Lampung Tengah, Indonesia \\ ${ }^{3}$ Department of Civil Engineering, Faculty of Engineering \\ Universitas Kristen Maranatha, Bandung, Indonesia \\ indra.koheru@indonesiaethanol.com, cindrawaty.lesmana@eng.maranatha.edu
}

(Received February 02, 2021, accepted February 22, 2021)

\begin{abstract}
The procurement process in construction is quite complicated with its various methods. One of them, design and construct contracting, which often used, is one that has an advantage of saving time and money. However, for companies without sufficient capabilities to carry out procurement, the design construct contract method also requires expert assistance in the process. To meet the construction procurement process requirements, one workable solution is that the company collaborates with a university for its factory construction development. The relevant academicians have expertise to solve problems in procurement process. The academician team was collecting appropriate data and then evaluating it to give suggestions on the construction procurement process. The method used was a simple comparison of the price proposed by the contractor to the owner estimate which was then calculated based on the Indonesian Regulation by the Minister of Public Works and Housing no. 28/PRT/M/concerning the unit price analysis that used as reference. Prices for materials, tools, and wages referred from Indonesian unit price journal references. The result of the evaluation was to determine the contract winner based on price and technical design aspects within company budget. During the evaluation process, clarification was made regarding the proposed design, construction method and quality of the proposed material to match the technical aspects of the design. The price evaluation process which was carried out in a short term has assisted the company in carrying out its construction procurement process. In the long run, cooperation can be developed in the form of human resource training so that the company can develop independently in carrying out the construction procurement process.
\end{abstract}

Keywords: construction procurement; community service; owner estimate 


\section{Introduction}

Construction procurement is the process of identification, selection, and commissioning of the inputs required to construct a project (Department of Business Innovation and Skills, 2012). The process basically carried out in every phase of project life cycle to get the selected consultant or contractor to produce design or progress output in every phase as shown in Fig. 1. Procurement processes are based on 3 principles, such as: best price, best quality, and best schedule. Those three principles are frequently used to select the consultant or contractor in each phase of the project life cycle.

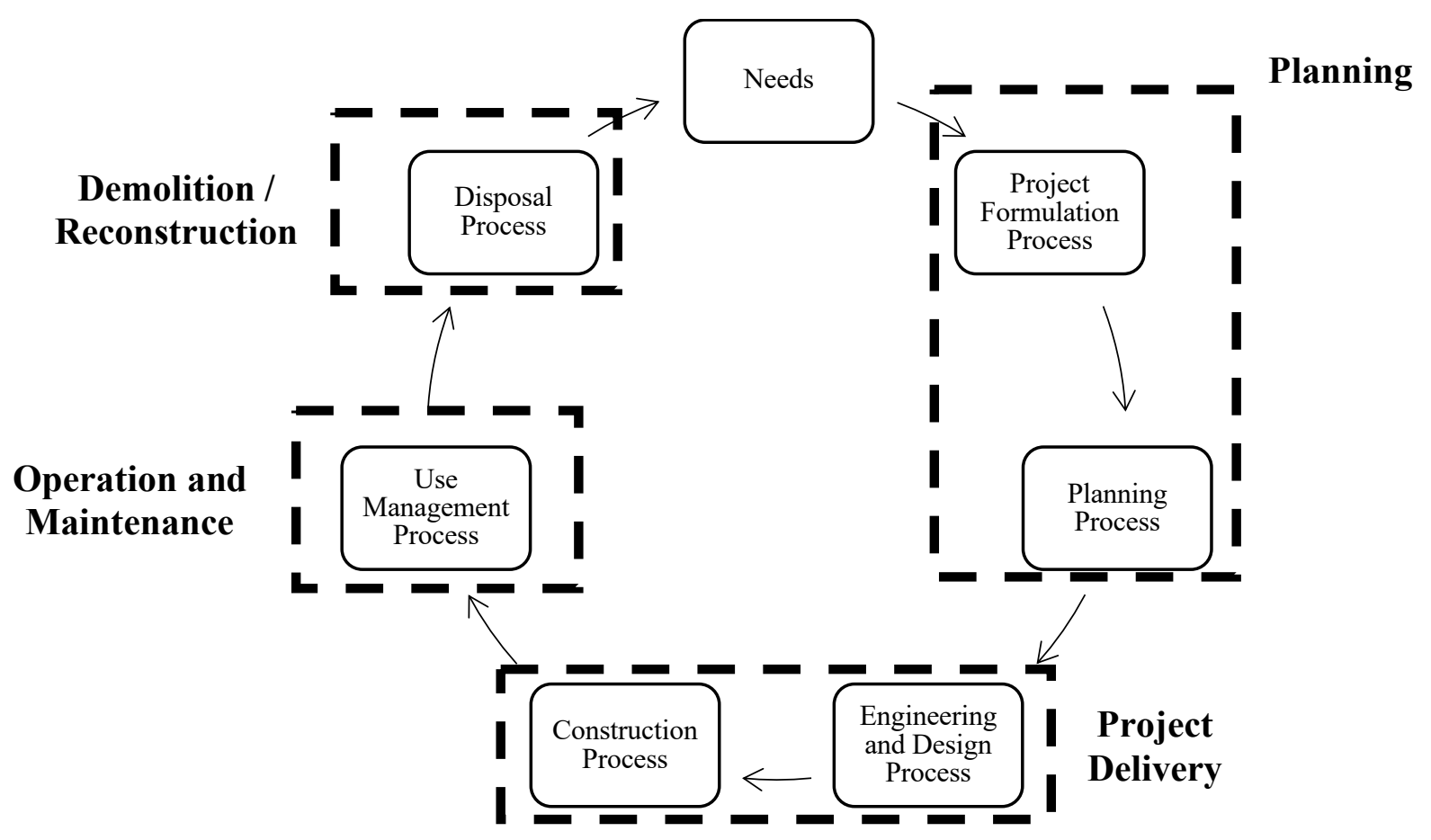

Fig. 1. Project Life Cycle (Z.Tamin, 2017)

The procurement process involves activities that consist of pre-contractual phase, the contracting phase, the contract administration phase, and the post-contractual phase as shown in Fig. 2. Pre-contractual phase consists of defining requirements, planning the procurement process, pre-tendering survey, and biding solicitation activities. The contracting phase consists of bidder selection, pre-bid conference, tender evaluation, and purchase order activities. The contract administration phase consists of issue contract amendments, monitor progress, follow up on delivery, and administer progress payments activities. The post-contractual phase consist of file final action contractor agreement to final claim, issue final contract amendment, 
complete of financial audits, check for proof of delivery, return of performance bonds and close-out, and ensure completeness and accuracy of file documentation activities.

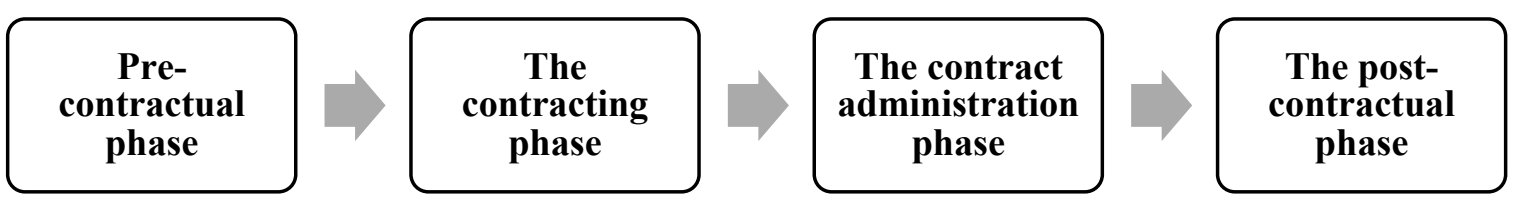

Fig. 2. Activities involved in the Procurement Process (Ruparathna \& Hewage, 2015)

The contract method cannot be separated from the construction procurement process. Choosing the type of construction project contract is one step to overcome risk in terms of avoiding risks in the legal aspects of a project (Milyardi, 2020). One of the procurement methods that generally used in Indonesia is Design and Construct Contracting. Design and Construct provide a single point of construction project contact for the client, where a single contractor is responsible for both design and construction (Ruparathna \& Hewage, 2015). In Design and Construct Contracting Method, the project concept is developed by the client with the assistance of a design consultant, for which proposals are called (Kelley, 2012). Despite of the advantage on resource in time and cost efficiency by implementing Design and Construct Contracting Method, the inflated cost can occur because the bidding is being done with minimal design or site data; less attention towards the life-cycle costs; and quality of construction work is highly dependent on the contractor (Walker, D., \& Hampson, 2008). In Indonesia, the selection of project delivery does not have much effect on construction project performance (Milyardi, Roi; Wirahadikusumah, Reini D.; Abduh, Muhamad; Siregar, 2020).

The case study in which this Design and Construct Contracting Method was applied was in the construction procurement at PT Indonesia Ethanol Industry (IEI), Lampung, Indonesia, which is a national scale ethanol production company. In order to fulfill its market needs, the company developed its production facilities. In December 2019, the company started to develop factory facilities, including renovating parts of the old factory, building the new factory, and so on. Previously, the company employees did not have full competence in civil work, so the project manager used to worry about reviewing the procurement process. PT IEI decided to use Design and Construct Method during the construction procurement due to the lack of ability in civil works and lack of adequate resources (time and cost). At the execution of the procurement, PT IEI considered having advisors to review incoming bids from local contractors and to ensure that the large investment in facilities development was not wasted. To ensure the construction 
procurement process success, PT IEI collaborated with the Department of Civil Engineering, Universitas Kristen Maranatha (UKM) to get advise in the procurement process for the implementation of the factory renovation work of their company in Central Lampung city, Lampung Province, Indonesia.

Team from UKM was willing to contribute expertise in the project in a form of community service. The purposes of this project were to gather the field data, to analyse the process, to evaluate incoming price bids from local contractors that go into the procurement process for a factory building project at PT IEI, Central Lampung City, Lampung Province, Indonesia, and to give relevant feedback to the company.

\section{Methods}

Research method used in this study was the comparison method. Price bids evaluation is one of the determining parameters in the selection of the winner of construction procurement (Tanubrata \& Setiaputri, 2010). The price bids data from local contractor were collected and analysed. The bid prices were calculated based on the proposed design of the building by local contractor, which restricted by some variables among others. These variables are available site area, needs of machine dimension and capacity, and needs of building capacity. The bid prices were analysed by comparing the proposed unit price from the contractor against the owner's estimated unit price, which was calculated with the standard reference for unit price analysis from Regulation of the Minister of Public Works and Public Housing of Indonesia no. 28/PRT/M/2016. This regulation intended as a reference for the unit price analysis in calculating costs development as completeness in the construction work process and a basic in compiling unit price analysis or owner's calculations estimate $(\mathrm{OE})$ and unit price analysis or engineering's estimate (EE) for handling civil works (PerMen PUPR No. 28/PRT/M/2016 tentang Pedoman Analisis Harga Satuan Pekerjaan Bidang Pekerjaan Umum, 2016). The use of ministerial regulations is usually used in the scope of government work, but in this study, the regulation applied on the private sector, hence, the reference is still valid to be used in determining the owner estimate price. For the unit price of materials, wages, and tools that was used in the analysis of the unit price of the work owner estimate was referred to the journal edition 38 for Lampung City (Pandu Bangun Persada Nusantara, 2019). These unit price journals are generally used by practitioners in Indonesia to determine the approximate price of a construction project. 
The timeframe for the activities began in December 2019 as an initial project between the 2 parties for the implementation of construction work procurement activities and progressed until July 2020. The activities were carried out in 2 different places, namely, at the factory location for field observations, and at the Universitas Kristen Maranatha campus for conducting analysis as shown in Fig. 3.

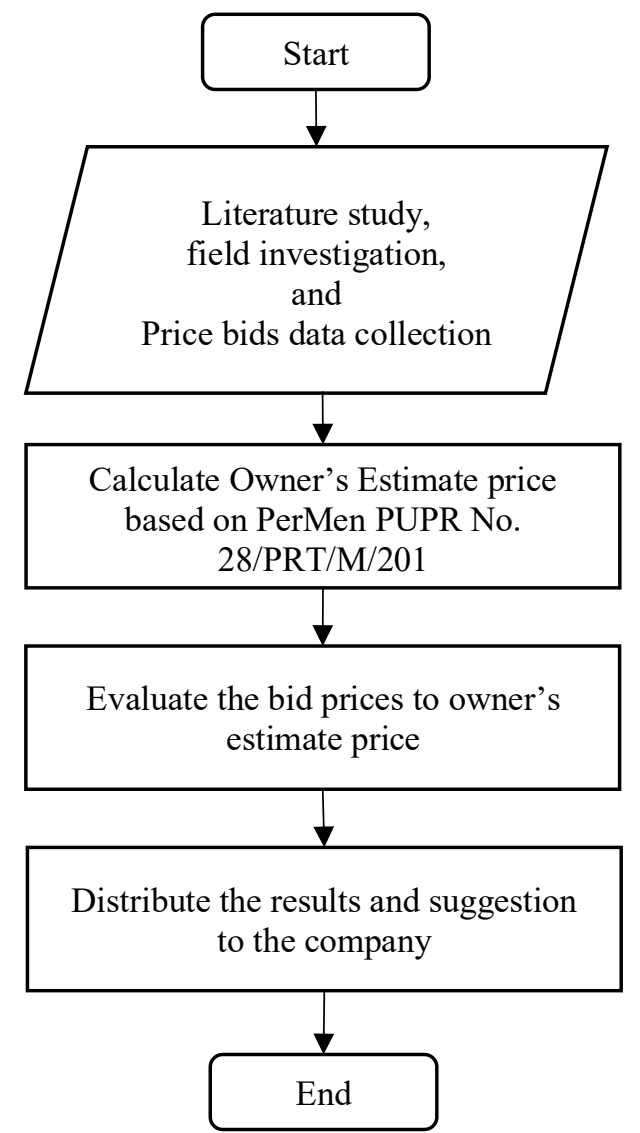

Fig. 3. Community Service Flow Chart Methodology

\section{Results and Discussions}

\section{Results}

Procurement evaluation was carried out on two projects. These projects were floodgate and lodging construction. In floodgate construction, the project provisions were limited to a land area of $339 \mathrm{~m}^{2}$ with the main structure of a $30 \mathrm{~m}$ long water channel shown in the Fig. 4 . The floodgate structure was the scope of the design work proposed by the contractor as part of the bid. 


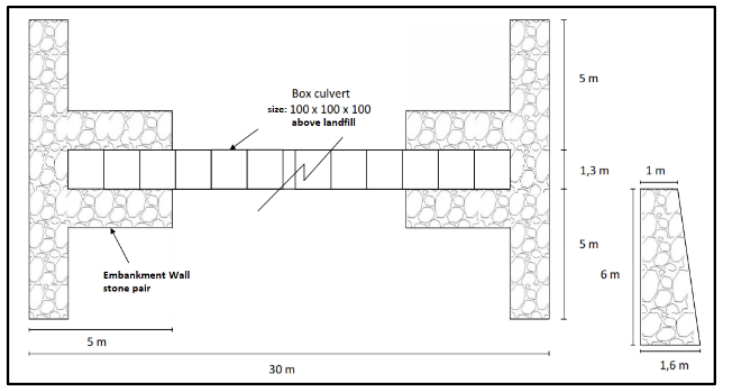

4(a). Floodgate Schematic Design Plan

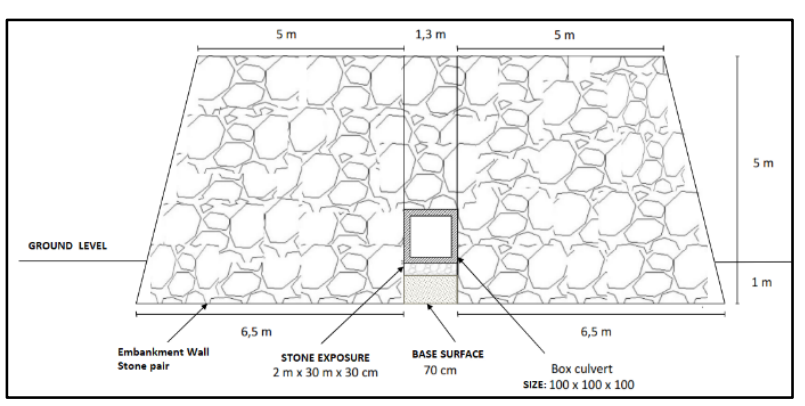

4(b). Floodgate Schematic Design Section

Fig. 4. Floodgate Schematic Design Drawing

The bid prices evaluation of Floodgate construction project on 2 local contractor bids shown in Table 1.

Table 1. Floodgate Construction Project Bid Price Evaluation

\begin{tabular}{|c|c|c|c|c|c|c|c|}
\hline \multirow{2}{*}{ No. } & \multirow{2}{*}{ Works } & \multicolumn{2}{|c|}{ Owner Estimate (OE) } & \multicolumn{2}{|c|}{ Local Contractor A bid } & \multicolumn{2}{|c|}{ Local Contractor B bid } \\
\hline & & Units & Unit price & Unit price & Evaluation & Unit price & Evaluation \\
\hline 1 & $\begin{array}{c}\text { Equipment } \\
\text { Mobilization } \\
\text { and } \\
\text { Demobilization } \\
\text { Labors }\end{array}$ & LS & - & $\begin{array}{c}\text { IDR } \\
2,500,000.00\end{array}$ & $\begin{array}{l}\text { to be } \\
\text { adjusted }\end{array}$ & $\begin{array}{c}\text { IDR } \\
3,000,000.00\end{array}$ & $\begin{array}{c}\text { to be } \\
\text { adjusted }\end{array}$ \\
\hline 2 & $\begin{array}{l}\text { Mobilization } \\
\text { and } \\
\text { Demobilization }\end{array}$ & LS & - & - & - & $\begin{array}{c}\text { IDR } \\
1,000,000.00\end{array}$ & $\begin{array}{c}\text { to be } \\
\text { adjusted }\end{array}$ \\
\hline 3 & OSH Equipment & LS & - & $\begin{array}{c}\text { IDR } \\
1,000,000.00\end{array}$ & $\begin{array}{l}\text { to be } \\
\text { adjusted }\end{array}$ & $\begin{array}{c}\text { IDR } \\
2,500,000.00\end{array}$ & $\begin{array}{l}\text { to be } \\
\text { adjusted }\end{array}$ \\
\hline 4 & Shop Drawing & LS & - & 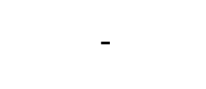 & - & $\begin{array}{c}\text { IDR } \\
4,000,000.00\end{array}$ & $\begin{array}{c}\text { to be } \\
\text { adjusted }\end{array}$ \\
\hline 5 & $\begin{array}{l}\text { Building board } \\
\text { installation and } \\
\text { measurement }\end{array}$ & LS & $\begin{array}{c}\text { IDR } \\
2,249,100.00\end{array}$ & $\begin{array}{c}\text { IDR } \\
1,500,000.00\end{array}$ & Below $O E$ & $\begin{array}{c}\text { IDR } \\
1,000,000.00\end{array}$ & Below $O E$ \\
\hline 6 & $\begin{array}{l}\text { Slice }+ \text { mortar } \\
\text { work }\end{array}$ & $\mathrm{m}^{3}$ & $\begin{array}{c}\text { IDR } \\
48,600.00\end{array}$ & $\begin{array}{c}\text { IDR } \\
740,025.00\end{array}$ & Exceed $O E$ & $\begin{array}{c}\text { IDR } \\
27,000.00\end{array}$ & Below $O E$ \\
\hline 7 & $\begin{array}{l}\text { Box culvert } \\
\text { installation }\end{array}$ & unit & $\begin{array}{c}\text { IDR } \\
3,191,155.00\end{array}$ & $\begin{array}{c}\text { IDR } \\
4,425,000.00\end{array}$ & Exceed $O E$ & $\begin{array}{c}\text { IDR } \\
4,661,083.95\end{array}$ & Exceed $O E$ \\
\hline 8 & $\begin{array}{l}\text { Installation of a } \\
\text { garbage filter } \\
\text { (D16mm) }\end{array}$ & $\mathrm{m}^{2}$ & $\begin{array}{c}\text { IDR } \\
392,890\end{array}$ & $\begin{array}{c}\text { IDR } \\
620,000\end{array}$ & Exceed $O E$ & $\begin{array}{c}\text { IDR } \\
450,000\end{array}$ & Exceed $O E$ \\
\hline & Mounting the & $\mathrm{m}^{1}$ & $\begin{array}{c}\text { IDR } \\
304,153\end{array}$ & $\begin{array}{c}\text { IDR } \\
400,000\end{array}$ & Exceed $O E$ & - & - \\
\hline 9 & $\begin{array}{l}\text { floodgate holder } \\
\text { (UNP 150) }\end{array}$ & $\mathrm{m}^{2}$ & $\begin{array}{c}\text { IDR } \\
912,495.00\end{array}$ & - & - & $\begin{array}{c}\text { IDR } \\
1,500,000\end{array}$ & Exceed $O E$ \\
\hline 10 & $\begin{array}{l}\text { Black stone } \\
\text { installation }\end{array}$ & $\mathrm{m}^{3}$ & $\begin{array}{c}\text { IDR } \\
904,550\end{array}$ & $\begin{array}{c}\text { IDR } \\
740,025\end{array}$ & Below $O E$ & $\begin{array}{l}\text { IDR } \\
531,175\end{array}$ & Below OE \\
\hline 11 & $\begin{array}{l}\text { Plaster of the } \\
\text { facade and top } \\
\text { walls }\end{array}$ & $\mathrm{m}^{2}$ & $\begin{array}{c}\text { IDR } \\
49,723\end{array}$ & $\begin{array}{c}\text { IDR } \\
50,006\end{array}$ & Exceed $O E$ & $\begin{array}{c}\text { IDR } \\
62,895\end{array}$ & Exceed $O E$ \\
\hline 12 & Cover the wall & $\mathrm{m}^{2}$ & $\begin{array}{c}\text { IDR } \\
32,063\end{array}$ & $\begin{array}{c}\text { IDR } \\
32,258\end{array}$ & Exceed $O E$ & $\begin{array}{l}\text { IDR } \\
62,985\end{array}$ & Exceed $O E$ \\
\hline 13 & Gabions & $\mathrm{m}^{3}$ & $\begin{array}{c}\text { IDR } \\
943,885 \\
\end{array}$ & $\begin{array}{c}\text { IDR } \\
740,025\end{array}$ & Below $O E$ & - & Below OE \\
\hline
\end{tabular}


In employee lodging construction project consists of 2 identical timber building, the project provisions were limited to a land area of $456.5 \mathrm{~m}^{2}$ for each lodging building shown in the 0 . The employee lodging detail design structure was the scope of the design work proposed by the contractor as part of the bid.

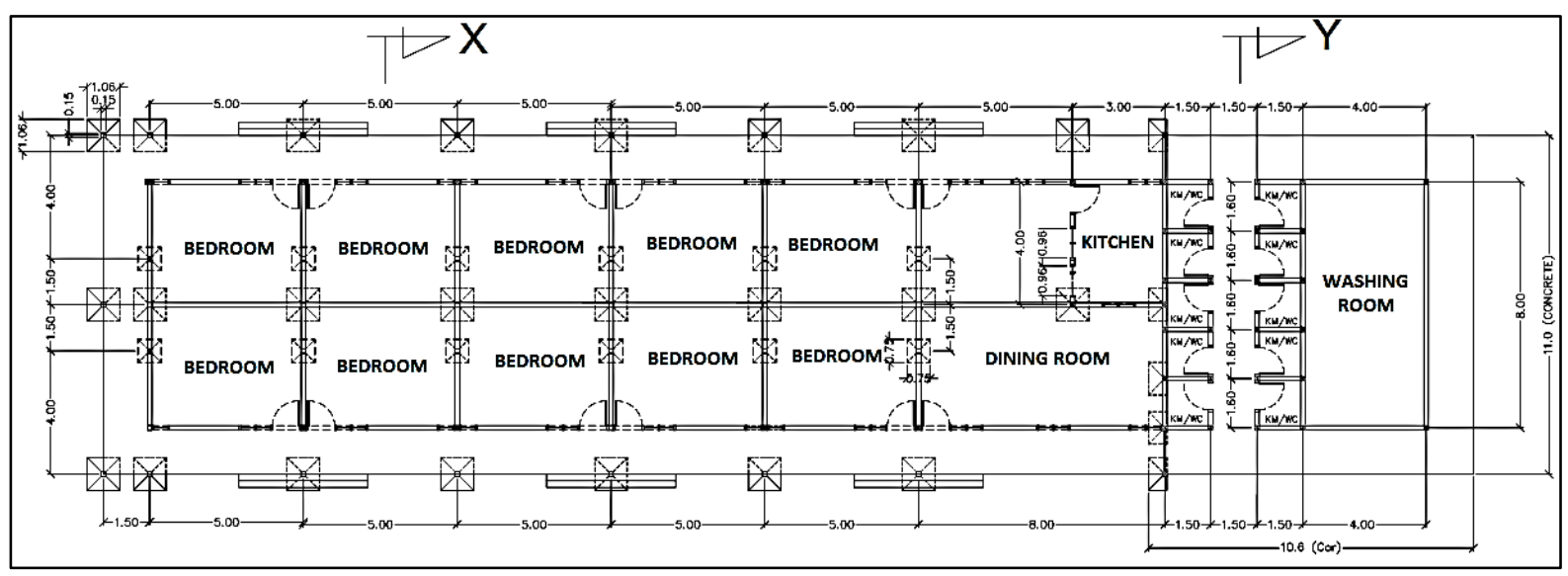

5(a). Employee Lodging Schematic Design Plan

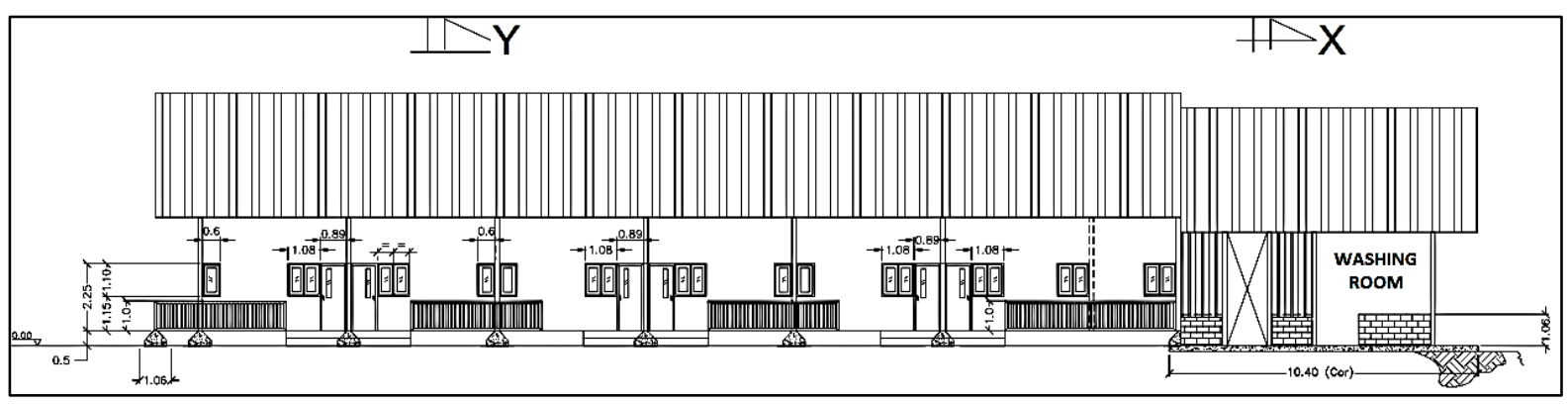

5(b). Employee Lodging Schematic Design Front View

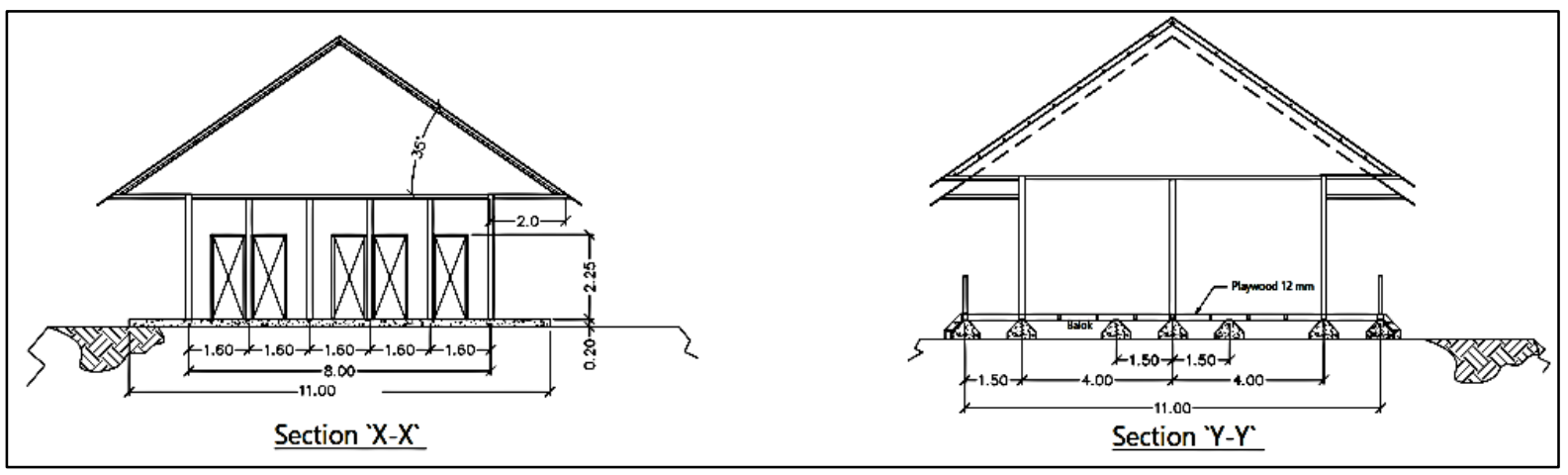

5(c). Employee Lodging Schematic Design Section

Fig. 5. Employee Lodging Schematic Design Drawing

The bid prices evaluation of employee lodging construction project on one local contractor bids shown in Table 2. 
Table 2. Employee Lodging Construction Project Bid Price Evaluation

\begin{tabular}{|c|c|c|c|c|c|}
\hline \multirow{2}{*}{ No. } & \multirow{2}{*}{ Works } & \multicolumn{2}{|c|}{ Owner Estimate (OE) } & \multicolumn{2}{|c|}{ Local Contractor bid } \\
\hline & & Units & Unit price & Unit price & Evaluation \\
\hline 1 & $\begin{array}{l}\text { Equipment Mobilization and } \\
\text { Demobilization }\end{array}$ & LS & - & $\begin{array}{c}\text { IDR } \\
1,000,000.00\end{array}$ & - \\
\hline 2 & $\begin{array}{c}\text { Building board installation and } \\
\text { measurement }\end{array}$ & $\mathrm{m}^{1}$ & $\begin{array}{c}\text { IDR } \\
112,215.00\end{array}$ & $\begin{array}{c}\text { IDR } \\
250,000.00\end{array}$ & Below OE \\
\hline 3 & OSH Equipment & LS & 然 & $\begin{array}{c}\text { IDR } \\
750,000.00\end{array}$ & - \\
\hline 4 & The split stone pillar Installation & $\mathrm{m}^{3}$ & $\begin{array}{c}\text { IDR } \\
767,150.00\end{array}$ & $\begin{array}{l}\text { IDR } \\
672,750.00\end{array}$ & Below OE \\
\hline 5 & Wood Floor Installation (6/12cm profile) & $\mathrm{m}^{3}$ & $\begin{array}{c}\text { IDR } \\
7,544,000.00\end{array}$ & $\begin{array}{c}\text { IDR } \\
7,413,250.00\end{array}$ & Below OE \\
\hline 6 & Plywood Installation (12mm) & $\mathrm{m}^{2}$ & $\begin{array}{c}\text { IDR } \\
279,300.00\end{array}$ & $\begin{array}{c}\text { IDR } \\
74,855.00\end{array}$ & Below OE \\
\hline 7 & $\begin{array}{l}\text { The Wooden beam column }(6 / 12 \mathrm{~cm} \text { profile }) \\
\text { Installation }\end{array}$ & $\mathrm{m}^{3}$ & $\begin{array}{c}\text { IDR } \\
7,544,000.00\end{array}$ & $\begin{array}{c}\text { IDR } \\
7,413,250.00\end{array}$ & Below OE \\
\hline 8 & The Partition Walls installation & $\mathrm{m}^{2}$ & $\begin{array}{c}\text { IDR } \\
359,032.00\end{array}$ & $\begin{array}{c}\text { IDR } \\
250,000.00\end{array}$ & Below OE \\
\hline 9 & Partition Wall Painting & $\mathrm{m}^{2}$ & $\begin{array}{l}\text { IDR } \\
17,218.00\end{array}$ & $\begin{array}{c}\text { IDR } \\
18,144.00\end{array}$ & $\begin{array}{c}\text { Exceed } \\
\text { OE }\end{array}$ \\
\hline 10 & Wood Door Installation & Unit & $\begin{array}{c}\text { IDR } \\
872,537.50\end{array}$ & $\begin{array}{c}\text { IDR } \\
1,231,538.00\end{array}$ & $\begin{array}{c}\text { Exceed } \\
\text { OE }\end{array}$ \\
\hline 11 & $\begin{array}{c}\text { The wooden double shutters window } \\
\text { installation }\end{array}$ & Unit & $\begin{array}{c}\text { IDR } \\
546,000\end{array}$ & $\begin{array}{l}\text { IDR } \\
654,671\end{array}$ & $\begin{array}{l}\text { Exceed } \\
\text { OE }\end{array}$ \\
\hline 12 & $\begin{array}{c}\text { The wooden single shutters window } \\
\text { installation }\end{array}$ & Unit & $\begin{array}{l}\text { IDR } \\
464,560\end{array}$ & $\begin{array}{l}\text { IDR } \\
363,706\end{array}$ & Below OE \\
\hline 13 & Concrete floor casting & $\mathrm{m}^{3}$ & $\begin{array}{c}\text { IDR } \\
1,059,916\end{array}$ & $\begin{array}{l}\text { IDR } \\
1,099,527\end{array}$ & $\begin{array}{c}\text { Exceed } \\
\text { OE }\end{array}$ \\
\hline 14 & the Brick Wall installation & $\mathrm{m}^{2}$ & $\begin{array}{l}\text { IDR } \\
87,685\end{array}$ & $\begin{array}{c}\text { IDR } \\
111,725\end{array}$ & $\begin{array}{c}\text { Exceed } \\
\mathrm{OE}\end{array}$ \\
\hline 15 & Plastering and wall cladding & $\mathrm{m}^{2}$ & $\begin{array}{c}\text { IDR } \\
61,500\end{array}$ & $\begin{array}{c}\text { IDR } \\
74,785\end{array}$ & $\begin{array}{c}\text { Exceed } \\
\mathrm{OE}\end{array}$ \\
\hline 16 & Brick wall painting & $\mathrm{m}^{2}$ & $\begin{array}{c}\text { IDR } \\
17,218\end{array}$ & $\begin{array}{c}\text { IDR } \\
18,144\end{array}$ & $\begin{array}{c}\text { Exceed } \\
\mathrm{OE}\end{array}$ \\
\hline 17 & Zinc-alum wall installation & $\mathrm{m}^{2}$ & $\begin{array}{c}\text { IDR } \\
92,020\end{array}$ & $\begin{array}{c}\text { IDR } \\
18,625\end{array}$ & Below OE \\
\hline 18 & Aluminum door installation & Unit & $\begin{array}{c}\text { IDR } \\
416,089\end{array}$ & $\begin{array}{c}\text { IDR } \\
522,342\end{array}$ & $\begin{array}{c}\text { Exceed } \\
\mathrm{OE}\end{array}$ \\
\hline 19 & Bidet installation & Unit & $\begin{array}{c}\text { IDR } \\
1,352,300\end{array}$ & $\begin{array}{c}\text { IDR } \\
1,990,700\end{array}$ & $\begin{array}{c}\text { Exceed } \\
\text { OE }\end{array}$ \\
\hline 20 & Water pipeline installation & - & 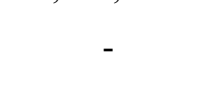 & $\begin{array}{c}\text { IDR } \\
500,000\end{array}$ & - \\
\hline 21 & Water faucet installation & Unit & $\begin{array}{c}\text { IDR } \\
108,750\end{array}$ & $\begin{array}{c}\text { IDR } \\
29,613\end{array}$ & Below OE \\
\hline 22 & Septic Tank installation & - & - & $\begin{array}{c}\text { IDR } \\
8,100,000\end{array}$ & - \\
\hline 23 & Brick stair installation & $\mathrm{m}^{2}$ & $\begin{array}{c}\text { IDR } \\
180,648\end{array}$ & $\begin{array}{c}\text { IDR } \\
111,725\end{array}$ & Below OE \\
\hline 24 & Cold form truss installation & Unit & $\begin{array}{c}\text { IDR } \\
327,239\end{array}$ & $\begin{array}{c}\text { IDR } \\
162,500\end{array}$ & Below OE \\
\hline 25 & Wooden fence installation & $\mathrm{m}^{2}$ & $\begin{array}{c}\text { IDR } \\
332,985\end{array}$ & $\begin{array}{c}\text { IDR } \\
128,900\end{array}$ & Below OE \\
\hline
\end{tabular}




\section{Discussions}

In floodgate construction project, the bid prices from local contractor A had more work items that were more expensive than $\mathrm{OE}$ ( 6 from 13 total work items were more expensive than $\mathrm{OE}$ ). The bid price of the local contractor B had more work items that were more expensive than OE ( 5 from 13 total work item were more expensive than OE). However, during the procurement process several clarifications were made regarding the design, construction method, and the quality of the proposed materials. For examples in the floodgate holder work item, both contractors had different calculation of unit price, so clarification for each calculation was required. Another example was in gabions item work, the difference between two contractors' bid prices could be observed since they have different design method. For prices that far exceed the standard, a bidding was made to determine the company budget. Finally, the community service teams gave the recommendation to the owner based on the results of bid prices from simple comparison analysis to save company budget.

In employee lodging construction project, there was only one bidder from local contractor. The bid prices had more work items that were cheaper than OE (12 from 25 total work items were more expensive than $\mathrm{OE}$ ). For prices that far exceed the standard, the bidding was made to determine the company budget. During the procurement process several clarifications also were made regarding the design, the construction method, the quality of the proposed materials, to ensure employee lodging meets the building quality requirements. Apart from the tender process, the community service team was also involved to oversee during the construction shown in Fig. 6.

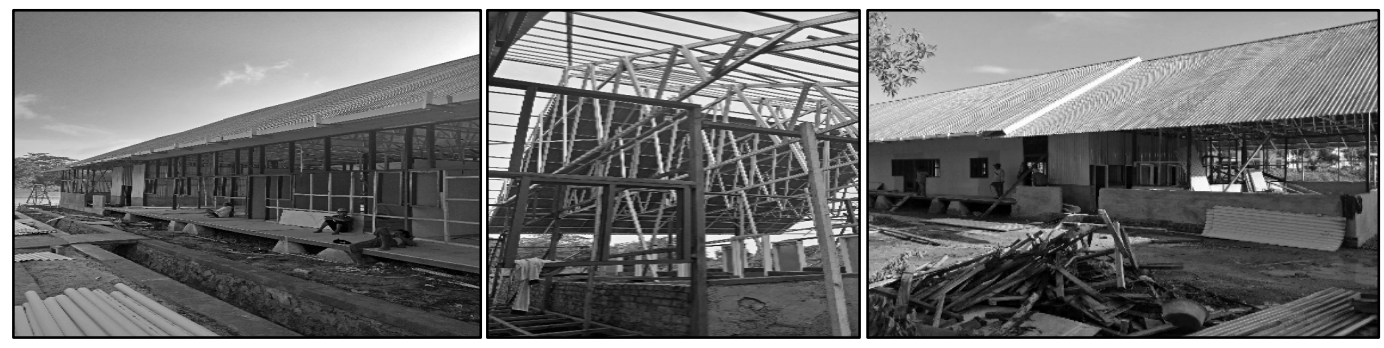

Fig. 6. Employee lodging construction progress

The simple comparison provided two information in the decision making on the tender winner. The first information obtained was information on comparison of the price of each work item. The second information was the grand total of the bid price information. The decision-making process was carried out by choosing the lower price than the owner estimate and the lowest grand total price. In order to make the decision, an additional clarification was required. The 
clarification helped the team to attain similar baseline on the specified targets, although the contractors had different design and construction methods. After the clarification process, the team obtained the final bid prices from the contractors. Comparing the final bid prices to the owner estimate prices, the team made decision based on simple comparison. Finally, the team suggested recommendation to the owner. Therefore, the company could have the suitable construction quality for the long-term investment with the minimum budget prices from the outcomes of this community service.

In this community service activity, the construction procurement evaluation process helped the company determine the tender winner based on the budgetary and technical design aspects, as an effort to cover the shortage of skilled personnel in the company. However, for the long term, it has been proposed to conduct training for existing employees as well as new employees in the future on basic skills in the tender process. With the existence of a continuous cooperation process in terms of training, companies can grow independently having capabilities in the field of construction procurement.

\section{Conclusion}

Based on the community service activities carried out at PT IEI, the procurement evaluation process carried out helped the company to maintain the available budget and to achieve the expected building quality. In the long run, the development of existing human resources can be carried out in the form of training on the basics of procurement evaluation so that companies can develop independently.

\section{Acknowledgements}

This community service was strongly supported by PT Indonesia Ethanol Industry (IEI), Lampung Tengah City, Bandar Lampung Province, which had welcomed us to make analysis and recommendation during the construction procurement phase of PT IEI factory facility. Hopefully the collaboration between Department of Civil Engineering, Universitas Kristen Maranatha and PT IEI will be able to continue and be sustainable for another community services in the future. 


\section{References}

Department of Business Innovation and Skills. (2012). "Construction procurement." Construction.

Kelley, G. (2012). Construction law: An introduction for engineers, archi- tects, and contractor. Wiley.

Milyardi, Roi; Wirahadikusumah, Reini D.; Abduh, Muhamad; Siregar, B. H. (2020). Construction Performance Analysis in the Project Delivery of Toll Road Concession. Jurnal Teknik Sipil, 27(1), 39-50.

Milyardi, R. (2020). PERBANDINGAN KARAKTERISTIK MANAJEMEN RISIKO KONSTRUKSI PADA KONTRAKTOR BUMN DAN SWASTA. Jurnal Teknik Sipil, 16(April 2020), 12-37.

PerMen PUPR No. 28/PRT/M/2016 tentang Pedoman Analisis Harga Satuan Pekerjaan Bidang Pekerjaan Umum, (2016).

Pandu Bangun Persada Nusantara. (2019). Jurnal Harga Satuan Bahan Bangunan, Konstruksi \& Interior Edisi 38. Pandu Bangun Persada Nusantara.

Ruparathna, R., \& Hewage, K. (2015). Review of Contemporary Construction Procurement Practices. Journal of Management in Engineering, 31(3), 04014038. https://doi.org/10.1061/(asce)me.1943-5479.0000279

Tanubrata, M., \& Setiaputri, M. (2010). Proses Evaluasi Penawaran Kontraktor. Jurnal Teknik Sipil, 6(2), 79-100.

Walker, D., \& Hampson, K. (Eds. . (2008). Procurement strategies: A relationship-based approach. John Wiley \& Sons.

Z.Tamin, R. (2017). Asosiasi Badan Usaha (Tantangannya dalam UU 2, 2017 Jasa Konstruksi). Gapeksindo. 